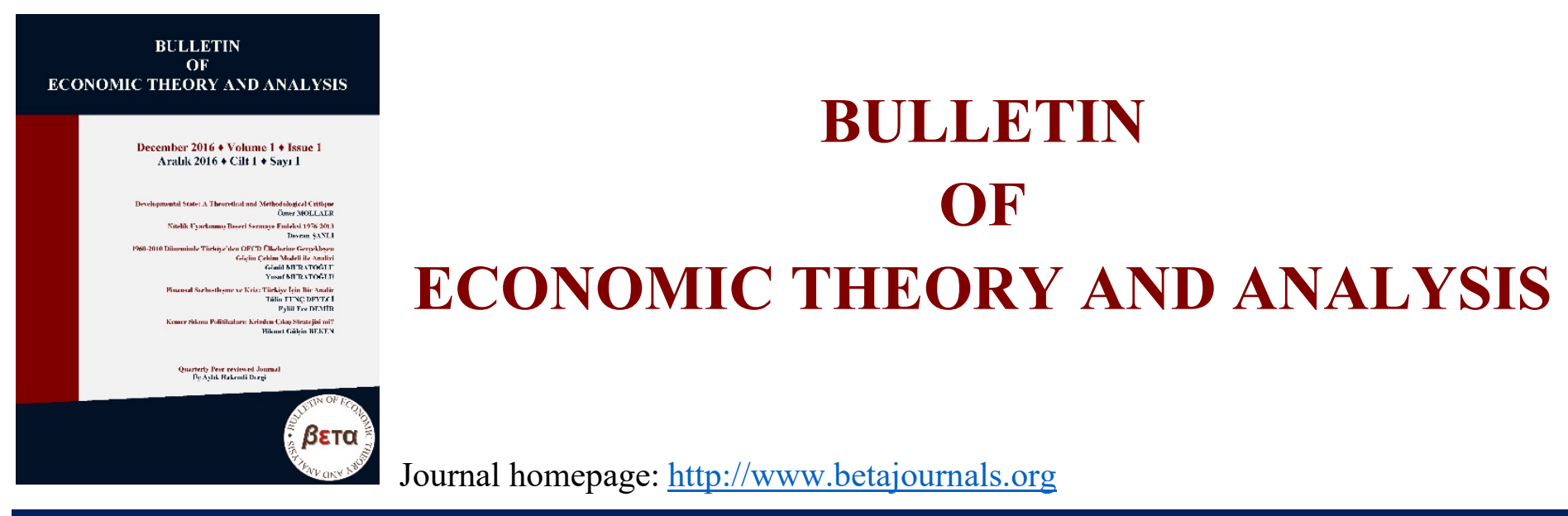

\title{
Finansal Performansın Oran Analizi ile Ölçülmesi: Teknoloji Sektöründe Faaliyet Gösteren Firmalar Üzerine Ampirik Bir Uygulama
}

\section{Zehra YOLOĞLU ำ https://orcid.org/0000-0003-1896-2673}

To cite this article: Yoloğlu, Z. (2021). Finansal Performansın Oran Analizi ile Ölçülmesi: Teknoloji Sektöründe Faaliyet Gösteren Firmalar Üzerine Ampirik Bir Uygulama. Bulletin of Economic Theory and Analysis, 6(2), 27-53.

Received: 29 May 2021

Accepted: 26 Oct 2021

Published online: 31 Dec 2021

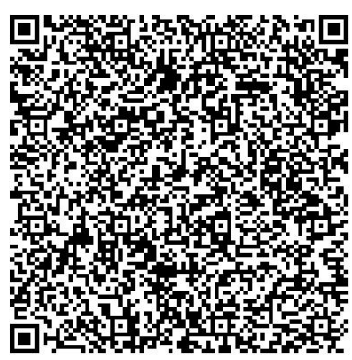




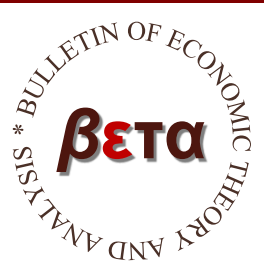

\section{Bulletin of Economic Theory and Analysis}

Volume VI, Issue 2, pp. 27-53, 2021

http://www.betajournals.org

Original Article / Araştırma Makalesi

Received / Alınma: 29.05.2021 Accepted / Kabul: 26.10.2021

\section{Finansal Performansın Oran Analizi ile Ölçülmesi: Teknoloji Sektöründe Faaliyet Gösteren Firmalar Üzerine Ampirik Bir Uygulama Zehra YOLOĞLUa \\ ${ }^{\mathrm{a}}$ Doktora Öğrencisi, Alanya Alaaddin Keykubat Üniversitesi Sosyal Bilimler Enstitüsü, İşletme Doktora Programı, Antalya, TÜRKIYE 1 https://orcid.org/0000-0003-1896-2673}

\section{ÖZ}

Bu çalıșmada, Borsa İstanbul'da işlem gören teknoloji firmalarının 2016-2020 yıllarına ait bilanço ve gelir tablosu kalemlerinden yararlanılarak oran analizi yöntemiyle finansal performansları tespit edilmiştir. Çalıșmanın amacı firmaların finansal performanslarını ölçmek olup, kapsamı dolayısıyla da Covid-19 salgınının firmaların mali (finansal) tabloları üzerindeki etkisini ortaya çıkarmaktır. Çalışmada kullanılan veriler Kamuyu Aydınlatma Platformu (KAP) ve Finnet internet sitesinden elde edilmiş olup Microsoft (MS) Excel bilgisayar programı ile analiz edilmiştir. Çalışmada oran analizi kapsamında firmaların likidite, faaliyet, finansal yapı ve kârlılık oranları incelenmiştir. Dönemler içinde hesaplanan firmaların likidite oranları standartlara göre uygun yani likidite durumlarının yeterli olduğu görülmektedir. Covid-19 salgının etkili olduğu 2020 yılında firmaların cari ve likidite oranlarında düşüş görülse de yine de kritik değerlerin üzerinde olduğu tespit edilmiştir. Ele alınan dönem içerisinde stok devir hızı ve dönen varlık devir hızı yüksek seviyelerdeyken 2020 yılında düşüş yaşanmıştır. Finansal yapı oranları incelendiğinde firmaların sermaye yapısının genellikle öz kaynaklardan oluştuğu borçlanma oranlarında ise kısa vadeli yabancı kaynak payının yüksek olduğu görülmektedir. Kârlılık oranları incelendiğinde ise yıllar içerisinde firmaların dalgalı bir seyirde ilerlediği ve 2018-2019 yıllarında negatif seviyelere düştüğü gözlemlenmektedir. Ancak salgın döneminde firmaların karlılık oranlarının yükseldiği tespit edilmiştir.

Anahtar Kelimeler

Covid-19, BIST 100, Oran Analizi

JEL Kodu G10, G20.

ILETIŞSiM Zehra YOLOĞLU $₫$ zehra_1484@hotmail.com $\equiv$ Alanya Alaaddin Keykubat Üniversitesi Sosyal Bilimler Enstitüsü, İşletme Doktora Programı, Antalya, Türkiye 


\title{
Measuring Financial Performance with Ratio Analysis: An Empirical Practice on Firms Operating in the Technology Sector
}

\begin{abstract}
In this study, financial performances of technology companies traded in Borsa Istanbul were determined by using ratio analysis method by using balance sheet and income statement items for the years 2016-2020. The aim of the study is to measure the financial performance of the companies and to reveal the impact of the Covid-19 epidemic on the financial (financial) statements of the companies. The data used in the study were obtained from the Public Disclosure Platform (KAP) and the Finnet website and analyzed with the Microsoft (MS) Excel computer program. In the study, the liquidity, activity, financial structure and profitability ratios of the companies were examined within the scope of ratio analysis. It is seen that the liquidity ratios of the companies calculated within the periods are appropriate according to the standards, that is, their liquidity status is sufficient. Although there was a decrease in the current and liquidity ratios of companies in 2020, when the Covid-19 epidemic was effective, it was still found to be above critical values. While the inventory turnover and current asset turnover were at high levels during the period under consideration, they decreased in 2020. When the financial structure ratios are analyzed, it is seen that the share of short-term liabilities is high in the borrowing ratios where the capital structure of the companies is generally composed of own resources. When the profitability ratios are examined, it is observed that the companies progressed in a fluctuating course over the years and fell to negative levels in 2018-2019. However, it was determined that the profitability rates of the companies increased during the epidemic period.
\end{abstract}

Keywords

Covid-19,

BIST 100,

Ratio Analysis.

JEL Classification G10, G20

\section{Giriș}

Covid-19 salgını bütün ülke ekonomilerini etkilediği gibi Türkiye ekonomisini ve dolayısıyla şirketleri de etkilemiştir. Covid-19 salgının ne kadar süreceğine dair belirsizlik ve ekonomideki yarattığı etkilerini ölçebilmek için yapılan çalışmalar salgının seyrinin belirsizliği nedeniyle sürekli güncel tutulmaktadır. Bu çalışmanın amacı da BIST 100'de işlem gören teknoloji şirketlerinin Covid-19'dan ne şekilde etkilendiklerini ortaya koymaktır. Bu şirketlerin seçilmesinde bilanço ve gelir tablolarına ulaşılabilir olması ve doğrudan mali tablolar üzerine yapılan çalışmaların sınırlı sayıda olması etkili olmuştur. Allianz (2020b) tarafından yapılan araştırmada Covid-19 salgının etkisiyle 2020 yılının ilk çeyreğinde 126 sektörün risk derecelendirmesinde düşüş yaşanmıştır. $\mathrm{Bu}$ düşüşün yaşanmasının sebebi ise şirketlerin talep, karlılık ve likidite üzerindeki etkilerinden dolayıdır. Şenol ve Zeren (2020) tarafından yapılan araştırmada Covid-19'un hisse senedi piyasaları üzerinde büyük etkileri bulunduğu sonucuna ulaşılmıştır. Hisse senedi fiyatlarında düşüşler meydana gelmiştir. Bu nedenle şirket ve finansal 
araçların değerleri kaybolmuş ve yatırımcılar çok fazla zarara uğramıştır. Şirketlerin ve finansal araçların değeri kaybolmuş ve yatırımcılar ciddi anlamda zarar etmiştir. Merkez Bankası Raporu'na (2020) göre, Covid-19'un sektörler üzerindeki yavaşlatıcı etkisi 2020 Mart ayından itibaren başlamıştır. Bu yavaşlatıcı etkiyi azaltmak için devlet tarafından kısa çalışma ödeneği ve istihdam öncelikli kredi uygulamaları ortaya koymuştur. Ancak yine de Covid-19 salgını tüm dünyadaki faaliyetleri etkilemiş ve uluslararası ticaret faaliyetlerinin daralmasına yol açmıştır.

$\mathrm{Bu}$ çalışmada BIST 100 işlem gören teknoloji şirketlerinin finansal performanslarını ölçmek ve Covid-19 salgının etkilerini ortaya koyabilmek amacıyla oran analizi yönteminden faydalanılmıştır. Oran analizi işletmelerin bilançosundaki aktifi ve pasifi ile gelir tablosundaki bağlantıları açıklayan bir analizdir. Oran analizinde önemli olan hesapların yorumlanması ve değerlendirilmesidir (Arat 2005:89). Oran analizi işletmelerin likit durumları, faaliyet yapıları, kârlılık durumları ve finansal yapısı hakkında bizlere bilgi vermektedir (Bakır ve Şahin, 2009:132). Likidite oranları işletmelerin kısa vadeli borçlarını ödeyebilme güçlerini ölçmeye yarayan oranlardır (Arat 2005:92). Bu oranlar; cari oran, asit test oranı ve nakit oran olarak ifade edilebilir. Cari oran işletmelerin kısa vadeli borçların ödeme gücünü ölçmek amacıyla kullanılan bir orandır. İşletmelerin net işletme sermayesinin yeterli olup olmadığı hakkında bilgi vermektedir. Dönen Varlıkların kısa vadeli yabancı kaynaklara oranlanmasıyla bulunmaktadır (Akgüç 2004:381). Asit test oranı olarak da adlandırılan likidite oranı işletmelerin kısa vadeli borçlarını, alacaklar ve nakit varlıklarla ödeyebilme gücünü gösterir ve cari orana göre daha başarılı bir ölçüm gerçekleştirir. Dönen varlıklardan stokların çıkarılması ve bu sonucun kısa vadeli yabancı kaynaklara oranlanmasıyla bulunur. (Akgüç 2004:387). Nakit oran işletmelerin nakit değerleri ile menkul değerlerin toplanması ve bu sonucun kısa vadeli yabancı kaynaklara bölünmesiyle bulunur. İşletmenin satışlarının durması veya alacaklarının tahsil edememesi durumunda kısa vadeli borçlarını karşılayabilme gücünü ortaya koyar. Faaliyet oranları işletmelerin faaliyetleri sırasında varlıklarını ve kaynaklarını ne derece etkin şekilde kullandığını ölçen oranlardır. Alacak devir hızı kredili satışların ticari alacaklara bölünmesiyle bulunur. İşletmelerin alacaklarını yılda kaç kere tahsil ettiğini gösteren bir orandır (Berk 1998 :40). Stok devir hızı satılan ticari mallar maliyetinin ticari mallar stok tutarına bölünmesiyle elde edilen orandır. İşletmenin stoklarının ne kadar süre içerisinde tükendiğini ve bir yıl içinde kaç defa stok devredildiğine dair bilgi vermektedir. Aktif devir hızı net satışların aktif toplama bölünmesiyle bulunur. İşletmenin gelir elde etmede varlıklarını ne derece etkin kullandığına dair bilgi verir (Berk 1998:45). Dönen varlık devir hızı net 
satışların dönen varlıklara bölünmesiyle bulunan orandır. İşletmenin dönen varlıklarının kaç katı kadar satış geliri sağladığını gösterir. Finansal yapı oranları işletmelerin finansal yapısı hakkında bilgi veren oranlardır. İşletmelerin finansal yapısındaki borç öz kaynak dengesinin ölçülmesinde kullanılan oranlardır. Borçlanma oranı yabancı kaynakların aktif toplama bölünmesiyle bulunur. $\mathrm{Bu}$ oranın diğer bir adı da finansal kaldıraç oranıdır. İşletmenin aktiflerinin ne kadarının yabancı kaynaklarla karşılandığını gösteren bir orandır. Öz kaynak oranı öz kaynakların aktif toplama bölünmesiyle bulunur. İşletmenin aktiflerinin ne kadarının öz kaynaklarla karşılandığını gösterir. Kısa vadeli yabancı kaynak oranı kısa vadeli yabancı kaynakların pasif (kaynaklar) toplamına bölünmesiyle bulunur. İşletmenin varlıklarının finansmanında kısa vadeli yabancı kaynağın oranını gösterir. Kârlılık oranları işletmelerin faaliyetlerinin sonucunda elde ettiği kârın ne derece yeterli olduğunu ölçen oranlardır (Akgüç 2004:427). Aktif kârlılık oranı dönem kârın aktif toplama bölünmesiyle bulunan orandır. İşletmede varlıkların ne derece kârlı kullanıldığının ölçülmesinde kullanılır. Öz kaynak kârlılık oranı dönem kârının öz kaynaklara bölünmesiyle bulunur. İşletme sermayesinin kârlılığını ölçmek için kullanılır. Net kâr marjı dönem kârının net satışlara bölünmesiyle bulunur. İşletmedeki faaliyetlerin verimliliği ile ilgili bilgilendirir. Brüt kâr marj1 brüt satış kârının net satışlara bölünmesiyle bulunur. İşletmelerin satış kârlılığı hakkında bilgilendirir.

Çalışmada, teknoloji sektöründe faaliyet gösteren firmaların 2016-2020 dönemindeki mali durumları analiz edilmiştir. Bu bağlamda, öncelikle konuya ilişkin ulusal ve uluslararası alanda gerçekleştirilmiş çalışmalarda elde edilen bulguları içeren literatür taramasına yer verilmiştir. Sonrasında finansal oran analizine ilişkin bilgilere değinilmiştir. Çalışmanın son bölümünde ise teknoloji firmaları üzerine gerçekleştirilen uygulamada elde edilen bulgular açıklanmış ve değerlendirmeler yapılmıştır. Çalışma, sonuç ve öneriler kısmı hazırlanarak tamamlanmıştır. Çalışmanın inceleme dönemi ve kapsamı doğrultusunda literatüre katkı sağlamakta ve özgünlük sunmaktadır.

\section{Alan Yazını}

Firmaların finansal performanslarının ölçülmesine yönelik olarak gerçekleştirilen önceki çalışmalar, kronolojik sıra ile aşağıda kısaca açıklanmıştır.

Uyar ve Okumuş (2010) tarafından yapılan çalışmada 2008 krizinin borsada işlem gören şirketler üzerindeki etkisini ölçmeyi amaçlanmıştır. Çalışmada oran analizi yöntemi kullanılmıştır. 
Çalışma sonucunda şirketlerin stok ve alacak devir hızlarında bir bozulma tespit edilmemiştir ancak karlılıklarında düşüş ve borç yapılarında değişik yaşandığı tespit edilmiştir.

Büyükşalvarcı (2011), yaptığı çalışmada 2001 ve 2008 krizlerinin finansal analizde kullanılan oranlarla hisse senedi getiri oranları üzerinde etkilerinin kriz dönemlerinde farklılık gösterip göstermediğini incelemiştir. Çalışmasını Borsa İstanbul'da işlem gören imalat sanayi şirketleri üzerinde yapmıştır. Çalışmada regresyon analizi kullanılmıştır. Çalışma sonucunda kriz döneminde finansal oran ile hisse senedi getirilerinin kriz dönemlerinde farklılık gösterdiği ve dalgalanmalar yaşandığı gözlemlenmiştir.

Gümüş ve Aydemir (2014) tarafindan yapılan çalışmada 2008 krizinin etkilerini ortaya koyabilmek için BIST 100 işlem gören şirketleri sektörel bazda incelemişlerdir. Çalışmada oran analizi yöntemi kullanılmıştır. Çalışma sonucunda krizin etkisiyle şirketlerin kısa vadeli borçlarını ödemede zorlandığını ve karlılıklarında düşüşler meydana geldiği sonucuna ulaşılmıştır.

Tayyar, Akcanlı, Genç ve Erem (2014), yaptıkları çalışmada Borsa İstanbul kayıtlı bilişim ve teknoloji sektöründe faaliyet gösteren şirketlerin 2005-2011 dönemine ilişkin finansal tablo verileri kullanılarak oran analizi gerçekleştirilmiştir. Analitik Hiyerarşi Prosesi yöntemi kullanılarak ağırlığı fazla olan kriter elde edilmeye çalışılmış, daha sonra Gri İlişkisel Analiz uygulanarak her bir işletme için yıllar itibariyle gri ilişskisel dereceleri hesaplanmıştır. Çalışmaların sonucunda en yüksek finansal performansa sahip işletmenin Link Bilgisayar Sistemleri Yazılımı ve Donanımı Sanayi ve Ticaret A.Ş olduğu belirlenmiştir.

Livinec ve Ayme-Dolla'ya (2017) tarafindan yapılan araştırmada alacak tahsil süresi en uzun olan ülkeler arasında Türkiye, İtalya, Yunanistan ve Çin bulunmaktadır. Vadelerin uzaması işletme sermaye gereksinimlerini arttırmaktadır. Bu nedenle özellikle salgın ve kriz dönemlerinde bu vadelerin iyileştirilmesi ve kontrollü bir şekilde ele alınması gerektiği belirtilmiştir.

Eren vd. (2020) tarafından yapılan çalışmada Covid-19 salgının BIST sektör endeks getirileri üzerindeki etkisi araştırılmıştır. Çalışma sonucunda Covid-19 salgının etkilerinin sadece reel sektörde değil finans sektörünü de olumsuz etkilediği sonucu ortaya çıkmıştır. Ayrıca çalışmada bazı sektörlerin pozitif yönlü etkilendiği de belirtilmiştir. Bu sektörler arasında gıda, kimya ve bankacılık sektörleri bulunmaktadır.

Dirk ve Allan (2020) tarafından yapılan çalışmada Covid-19 etkilerini Avusturya Borsasına kayıtlı şirketler üzerinden ölçmüşlerdir. Çalışma sonucunda Covid-19 döneminde bazı şirket kayıp 
oranlarının \%75'leri bulduğu tespit edilmiştir. Ayrıca salgından en fazla petrol, GYO'lar, inşaat malzemeleri, finans ve bankacılık sektörünün etkilendiği belirtilmiştir.

Liu vd. (2020) tarafından yapılan çalışmada Şanghay ve Shenzen Borsalarında işlem gören şirketlerin hisse fiyatları üzerinden, Çin şirketlerinin Covid-19 dönemindeki performanslarını ortaya koymuşlardır. Çalışma sonucunda Covid-19 döneminden en çok olumsuz etkilenen sektörlerin ulaşım, madencilik, elektrik olduğu, olumlu etkilenen sektörlerin ise imalat, bilgi teknolojisi, eğitim ve sağlık hizmetleri olduğunu tespit etmişlerdir.

Khan vd. (2020) tarafından yapılan araştırmada16 ülkenin borsalarına ait hisse senedi endekslerinin Covid-19 salgınından ne yönde etkilendiğini ortaya koymuşlardır. Çalışma sonucunda borsa hisse senedi endekslerinin olumsuz etkilendiği sonucuna ulaşılmıştır. Çalışmadan çıkan bir başka sonuç ise bu olumsuz etkinin salgının insandan insana bulaştığının açıklanmasından sonra daha da arttığını ortaya koymuştur.

Elsayed ve Elrhim (2020) tarafindan yapılan çalışmada Mısır Borsası'nda işlem gören 17 sektörün, Covid-19 salgınından ne yönde etkilendiğini ortaya koymuşlardır. Araştırma sonucunda borsanın günlük ölüm ve vaka sayılarından çok kümülatif ölüm ve vaka sayılarına daha çok tepki verdiğini sonucuna ulaşılmıştır.

Hamim (2020), Covid-19'un Bangladeș Dakka Borsası (DSE) üzerindeki etkisini araştırmıştır. Covid-19 salgının etkisiyle 4000 puanın altına düşmüş ve 5 milyar Amerikan dolarından fazla değer kaybetmiştir. 25 Mart'ta borsa kapanmıştır. Çalışma sonucunda istihdamın azalacağı, yatırımların düşeceği, vergi gelirlerinin azalacağı ve itibar kaybının doğacağı sonucuna ulaşılmıştır.

\section{Metodoloji}

\subsection{Araştırmanın Amacı ve Kapsamı}

Araştırmada BIST teknoloji sektöründe faaliyet gösteren şirketlerin finansal performansları ölçmek amaçlanmaktadır. Çalışmanın kapsamı 2016-2020 döneminde BIST te faaliyet gösteren on dört teknoloji şirketi ve bu şirketlerin verilerinden oluşmaktadır.

Çalışmada sektöre ait veriler Kamu Aydınlatma Platformu ve Finnet internet sitesinden elde edilmiştir. Veri yetersizliği nedeniyle on dört şirket çalışma kapsamında incelenmiştir. FONET ve 
ANELT şirketi incelenen dönemdeki veri yetersizliği nedeniyle kapsam dışı bırakılmıştır. Araştırmaya dahil edilen şirketler; Tablo 1 de gösterilmiştir.

Tablo 1

Borsa İstanbul Teknoloji Sektöründe Faaliyet Gösteren Şirketler

\begin{tabular}{ll}
\hline Kodu & \multicolumn{1}{c}{ Şirketler } \\
\hline ALCTL & Alcatel Lucent Teletaş Telekomünikasyon A.Ş. \\
ARENA & Arena Bılgısayar Sanayı ve Tıcaret A.Ş \\
ARMDA & Armada Bilgisayar Sistemleri Sanayi ve Ticaret A.Ş. \\
ASELS & Aselsan Elektronik Sanayi ve Ticaret A.Ş. \\
DGATE & Datagate Bilgisayar Malzemeleri Ticaret A.Ş. \\
DESPC & Despec Bilgisayar Pazarlama ve Ticaret A.Ş. \\
ESCOM & Escort Teknoloji Yatırım A.Ş. \\
INDES & İndeks Bilgisayar Sistemleri Mühendislik Sanayi ve Ticaret A.Ş. \\
KÂREL & Kârel Elektronik Sanayi Ve Ticaret A.Ş. \\
KRONT & Kron Telekomünikasyon Hizmetleri A.Ş. \\
LINK & Link Bilgisayar Sistemleri Yazılımı ve Donanımı Sanayi ve Ticaret A.Ş. \\
LOGO & Logo Yazılım Sanayi ve Ticaret A.Ş. \\
NETAS & Netaş Telekomünikasyon A.Ş. \\
PKART & Plastikkârt Akıllı Kârt İletişim Sistemleri Sanayi ve Ticaret A.Ş. \\
\hline
\end{tabular}

\subsection{Araştırmanın Yöntemi}

Yapılan çalışmada BIST teknoloji sektöründe faaliyet gösteren şirketlerin finansal performanslarının ölçülmesinde finansal oran analizi kullanılmıştır.

Tablo 2

Analizde Kullanılan Finansal Oranlar

\begin{tabular}{lll}
\hline Değişken & Kodu & Hesaplama yöntemi \\
\hline Cari Oran & (CO) & Dönen Varlıklar / Kısa Vadeli Yabancı Kaynaklar \\
Likidite Oranı & (LO) & Dönen Varlık-Stoklar/ Kısa Vadeli Yabancı \\
& Kaynaklar \\
Nakit Oran & (NO) & Nakit ve Benzeri/ Kısa Vadeli Yabancı Kaynaklar \\
Aktif Devir Hızı & (AKDH) & Net Satışlar/ Aktif Toplamı \\
Alacak Devir Hızı & $($ ADH) & Net Satışlar/ Ticari Alacaklar \\
Stok Devir Hızı & (SDH) & Satı̧̧ların Maliyeti/ Stoklar \\
Dönen Varlıkların Devir Hızı & (DVDH) & Net Satışlar/Dönen Varlıklar \\
Öz Kaynak Oranı & (ÖO) & Öz Kaynaklar/ Pasif Toplam \\
Borçlanma Oranı & (BO) & Toplam Yabancı Kaynak/ Aktif Toplam \\
\hline
\end{tabular}


K1sa Vadeli Yabanc1 Kaynak Oranı

Aktif Kârlılık Oranı

Öz Kaynak Kârlılık Oranı

Net Kâr Marj1

Brüt Kâr Marj1
(KVYK) Kısa Vadeli Yabancı Kaynaklar/ Aktif Toplam

(AK) Dönem Kâr/ Aktif Toplam

(ÖK) Dönem Kâr/ Öz Kaynaklar

(NK) Dönem Kâr/ Net Satışlar

(BK) Brüt Satıș Kârı/ Net Satıșlar

\subsection{Araştırmanın Bulguları}

Çalışmada incelenen on dört şirketin 2016-2020 dönemine ait analiz sonuçları ilgili oranlar itibariyle her yıl ayrı tablolar halinde gösterilmiştir. 
Tablo 3

BIST Teknoloji Sektöründe Faaliyet Gösteren Firmaların 2016 yılı Oran Analizi Sonuçları

\begin{tabular}{|c|c|c|c|c|c|c|c|c|c|c|c|c|c|c|}
\hline \multirow{2}{*}{ FİRMA } & \multicolumn{3}{|c|}{ LİKIDITTE ORANLARI } & \multicolumn{4}{|c|}{ FAALIYET ORANLARI } & \multicolumn{3}{|c|}{ FINANSAL YAPI ORANLARI } & \multicolumn{4}{|c|}{ KÂRLILIK ORANLARI } \\
\hline & $\mathrm{CO}$ & LO & NO & AKDH & ADH & SDH & DVDH & ÖO & BO & KVYKO & AK & ÖK & NK & BRTK \\
\hline ALCTL & 1,54 & 1,3 & 0,2 & 1,3 & 2,65 & 14,44 & 1,34 & 0,35 & 0,64 & 0,56 & 0,09 & 0,26 & 0,08 & 0,19 \\
\hline ARENA & 1,56 & 1,12 & 0,05 & 2,61 & 4,43 & 9,51 & 2,22 & 0,35 & 0,64 & 0,63 & 0,02 & 0,05 & 0,009 & 0,06 \\
\hline ARMDA & 1,56 & 1,33 & 0,14 & 2,1 & 3,34 & 13,47 & 1,92 & 0,25 & 0,75 & 0,63 & 0,01 & 0,06 & 0,007 & 0,06 \\
\hline ASELS & 2,26 & 1,64 & 0,52 & 0,47 & 2,7 & 2,56 & 0,74 & 0,42 & 0,57 & 0,26 & 0,09 & 0,21 & 0,21 & 0,24 \\
\hline DESPC & 2,8 & 1,76 & 0,11 & 2,47 & 4,47 & 7,19 & 2,25 & 0,64 & 0,35 & 0,35 & 0,12 & 0,18 & 0,05 & 0,08 \\
\hline DGATE & 1,27 & 1,13 & 0,19 & 4,25 & 5,27 & 33,28 & 4,13 & 0,24 & 0,76 & 0,75 & 0,05 & 0,24 & 0,02 & 0,03 \\
\hline ESCOM & 2,2 & 2,2 & 0,08 & 0,01 & 0,36 & 2 & 0,1 & 0,93 & 0,07 & 0,06 & 0,04 & 0,05 & 2,99 & 0,98 \\
\hline INDES & 1,14 & 0,97 & 0,21 & 3,11 & 4,92 & 17,64 & 2,79 & 0,13 & 0,84 & 0,84 & 0,03 & 0,27 & 0,01 & 0,04 \\
\hline KÂREL & 1,76 & 1,17 & 0,31 & 0,74 & 2,65 & 2,35 & 1 & 0,39 & 0,60 & 0,40 & 0,02 & 0,05 & 0,03 & 0,20 \\
\hline KRONT & 3,32 & 3,19 & 0,21 & 0,76 & 1,53 & 5,11 & 0,86 & 0,76 & 0,23 & 0,22 & 0,29 & 0,38 & 0,46 & 0,82 \\
\hline LINK & 8,96 & 8,94 & 6,59 & 0,44 & 2,78 & 91,57 & 0,48 & 0,88 & 0,12 & 0,09 & 0,06 & 0,08 & 0,19 & 0,66 \\
\hline LOGO & 0,94 & 0,93 & 0,29 & 0,62 & 3,26 & 15,04 & 1,36 & 0,49 & 0,48 & 0,45 & 0,14 & 0,28 & 0,24 & 0,97 \\
\hline NETAS & 1,43 & 1,06 & 0,15 & 0,76 & 1,65 & 8,79 & 0,86 & 0,39 & 0,60 & 0,57 & 0,01 & 0,03 & 0,02 & 0,14 \\
\hline PKART & 3,54 & 2,83 & 1,61 & 1,71 & 6,86 & 7,1 & 2,13 & 0,75 & 0,24 & 0,22 & 0,08 & 0,09 & 0,04 & 0,08 \\
\hline Ortalama & 2,45 & 2,11 & 0,76 & 1,52 & 3,35 & 16,43 & 1,58 & $\mathbf{0 , 5 0}$ & 0,49 & $\mathbf{0 , 4 3}$ & $\mathbf{0 , 0 7}$ & 0,16 & $\mathbf{0 , 3 1}$ & $\mathbf{0 , 3 3}$ \\
\hline
\end{tabular}


Tablo 3 de BIST teknoloji sektöründe faaliyet gösteren firmaların 2016 yılı likidite, faaliyet, finansal ve kârlılık oranları verilmiştir. Analiz sonuçları likidite oranlarına bakıldığında cari oran, likidite oranı ve nakit oranı sektör ortalamaları sırasıyla 2,45-2,11 ve 0,76 dır. Cari orana bakıldığında sektör ortalamasının altında 10 firma, sektör ortalamasının üstünde ise 4 firma bulunmaktadır. Likidite oranına bakıldığında sektör ortalamasının altında 10 firma, sektör ortalamasının üstünde ise 4 firma bulunmaktadır. Nakit orana bakıldığında ise sektör ortalamasının altında 12, sektör ortalamasının üstünde ise 2 firma bulunmaktadır. Cari oranın 2 olması likidite durumunun yeterli seviyede olduğunu göstermektedir. Cari oranının 2'den düşük olması firmaların likidite sıkıntısı çektiğini ve yükümlülüklerini karşılayamadığını gösterir. Cari oranın 2 den yüksek olması ise işletmede çok fazla dönen varlık olduğunu gösterir. 2016 yılında teknoloji firmalarının cari oran ortalaması kritik değerden yüksek olması firmalarda gereğinden fazla dönen varlık olduğunu ve firmaların atıl kaynaklarının bulunduğunun göstergesidir. Likidite oranının 1 olması beklenmektedir. Bu oranın 1 in altına düşmesi işletmenin borç ödeme gücü açısından zayıf, yüksek olması ise işletmenin ödeme gücünün yüksek olduğunun göstergesidir. 2016 yılında teknoloji firmalarının likidite oran ortalaması kritik değerden yüksek olması firmaların ödeme gücünün yüksek olduğunu göstermektedir. Nakit oranı ise 0,20 civarında olması ve altına düşmemesi beklenir. Şirketlerin nakit oran ve menkul kıymetleri ile kısa vadeli borç ödeyebilme gücünü gösterir. 2016 yılında teknoloji firmalarının nakit oran ortalaması kritik değerden yüksek olması şirketlerin kısa vadeli borç ödeyebilme yeteneğinin yüksek olduğunu göstermektedir.2016 y1lında cari, likidite ve nakit oran ortalamaları kritik değerden yüksek olması firmaların likidite düzeylerinin yeterli olduğunu göstermektedir.

Analiz sonucunda faaliyet oranlarına bakıldığında aktif devir hızı, alacak devir hızı, stok devir hızı, dönen varlıkların devir hızı sektör ortalaması sırasıyla 1,52- 3,35-16,43 ve 1,58'dir. Buna göre aktif devir hızında sektör ortalamasının üstünde 6 firma varken, sektör ortalamasının altında 8 firma bulunmaktadır. Alacak devir hızında sektör ortalamasının üstünde 5 firma varken, sektör ortalamasının altında 9 firma bulunmaktadır. Stok devir hızında sektör ortalamasının üstünde 3 firma varken, sektör ortalamasının altında 11 firma bulunmaktadır. Dönen varlık devir hızında sektör ortalamasının üstünde 6 firma varken, sektör ortalamasının altında 8 firma bulunmaktadır. Aktif devir hızı işletmelerin aktifleriyle elde etiği satış hacmi başarısını gösterir. Alacak devir hızı şirketlerin borçlarını tahsil etmedeki gücünü gösterir. 2016 yılında teknoloji firmalarına bakıldığında ortalamanın üzerinde firma sayısı az olması bize bu firmaların alacaklarını tahsil yeteneğinin başarısız olduğunun göstergesidir. Stok devir hızı 
2016 teknoloji firmalarına bakıldığında yüksek seviyelerde seyretmiştir. Stokların yüksek düzeyde tutulduğu ve kullanıldığını göstermektedir. Dönen varlık devir hızı düşük seviyelerde seyretmesi firmaların gereğinden fazla dönen varlılara sahip olduğunu göstermektedir. 2016 yılında teknoloji firmalarının faaliyet oranlarına bakıldığında aktif devir hızının yüksek seviyede olması, stok düzeyinin yüksek olması firmaların maddi duran varlıklara yüksek yatırımlar yapıp stok düzeyinin yüksek olduğunu göstermektedir. Ancak firmaların alacak tahsil yeteneğinin başarısız olduğu görülmektedir.

Finansal yapı oranlarına bakıldığında öz kaynak oranı, borçlanma oranı ve kısa vadeli yabancı kaynak oranı sektör ortalamaları sırasıyla 0,50- 0,49 ve 0,43 dir. Buna göre öz kaynak oranında sektör ortalamasının üstünde 5 firma varken sektör ortalamasının altında 9 firma bulunmaktadır. Borçlanma oranında sektör ortalamasının üstünde 8 firma bulunurken sektör ortalamasının altında 6 firma bulunmaktadır. Kısa vadeli yabancı kaynak oranında ise sektör ortalamasının üstünde 7 firma bulunurken sektör ortalamasının altında 7 firma vardır. Öz kaynak oranı aktiflerin ne kadarının öz kaynakla finanse edildiğini gösterir. Öz kaynak oranının \%50 seviyesinde seyretmesi öngörülmektedir. 2016 teknoloji firmaları ortalaması bu değerdedir ve bu da işletmelerin uzun süreli borçları ve faizleri ödemede zorluk yaşamayacağını gösterir. Borçlanma oranının 0.50 civarlarında seyretmesi öngörülmektedir. Bu şirketlerin aktiflerinin ne kadarının yabancı kaynaklarla karşılandığını gösterir. Firmaların yüksek faizli kredilerin altına girmediği ve ödeme güçlügü yaşamadıklarını göstermektedir. Kısa vadeli yabancı kaynak oranı ise işletmenin varlıklarının ne kadarının kısa vadeli borçlarla karşılandığını göstermektedir. Bu oranın yüksek olması varlıkların çoğunun kısa vadeli yabancı kaynaklarla finanse edildiğini ifade etmektedir. Kabul görmüş oran 1/3 civarında seyretmesidir (Çabuk ve Lazol, 2009: 215). 2012 yılı teknoloji firmaları incelendiğinde firmaların aktiflerinin daha çok öz kaynak ile finanse edildiğini görmekteyiz. Yabancı kaynak oranının 0,50 düzeyinde seyretmesi ve kısa vadeli yabancı kaynak oranının 1/3 kritik değere uyum sağlaması bu şirketlerin sağlam bir finansal yapıya sahip olduklarını göstermektedir.

Kârlılık oranlarına bakıldı̆̆ında aktif kârlılık, öz kaynak kârlılık, net kâr marjı ve brüt kâr marjı sektör oranları sırasıyla 0,07- 0,16- 0,31 ve 0,33 dur. Buna göre aktif kârlılık oranında sektör ortalamasının üstünde 6 firma bulunurken, sektör ortalamasının altında 8 firma bulunmaktadır. Öz kaynak kârlılık oranında sektör ortalamasının üstünde 7 firma bulunurken sektör ortalamasının altında 7 firma bulunmaktadır. Net kâr marjında sektör ortalamasının üstünde 2 firma bulunurken sektör ortalamasının altında 12 firma bulunmaktadır. Brüt kâr marjında sektör ortalamasının üstünde 4 firma bulunurken sektör ortalamasının altında 10 firma 
bulunmaktadır. Aktif kârlılık oranının yüksek seviyelerde olmaması firmaların varlıklarını verimli kullanamadığını göstermektedir. Öz kaynak kârlılık ortalamasının aktif kârlılık ortalamasına göre daha iyi seviyelerde olduğu söylenebilir. Yani firmaların iyi yatırımlar yapıp giderlerini kontrol altında tuttukları söylenebilir. Net kâr marjının ve brüt kâr marjının düşük seviyelerde seyretmesi firmaların giderleri karşılamada güçlük çekebileceğini göstermektedir. Sektör kârlılık durumundan pek başarılı görülmemektedir. 
Tablo 4

BIST Teknoloji Sektöründe Faaliyet Gösteren Firmaların 2017 yılı Oran Analizi Sonuçları

\begin{tabular}{|c|c|c|c|c|c|c|c|c|c|c|c|c|c|c|}
\hline \multirow{2}{*}{ FİRMA } & \multicolumn{3}{|c|}{ LİKİDİTE ORANLARI } & \multicolumn{4}{|c|}{ FAALIYET ORANLARI } & \multicolumn{3}{|c|}{ FINANSAL YAPI ORANLARI } & \multicolumn{4}{|c|}{ KÂRLILIK ORANLARI } \\
\hline & $\mathrm{CO}$ & LO & NO & AKDH & ADH & SDH & DVDH & ÖO & BO & KVYKO & AK & ÖK & NK & BRTK \\
\hline ALCTL & 2,18 & 1,76 & 0,36 & 1,15 & 2,60 & 8,71 & 1,36 & 0,40 & 0,60 & 0,38 & 0,05 & 0,14 & 0,05 & 0,14 \\
\hline ARENA & 1,44 & 1,06 & 0,13 & 2,33 & 4,62 & 9,62 & 2,37 & 0,31 & 0,68 & 0,68 & 0,003 & 0,008 & 0,001 & 0,05 \\
\hline ARMDA & 1,44 & 1,24 & 0,16 & 2,04 & 3 & 14,70 & 2,065 & 0,21 & 0,78 & 0,68 & 0,02 & 0,32 & 0,25 & 0,05 \\
\hline ASELS & 1,64 & 0,97 & 0,34 & 0,53 & 3,35 & 2,36 & 0,97 & 0,41 & 0,59 & 0,32 & 0,09 & 0,15 & 0,03 & 0,27 \\
\hline DESPC & 2,14 & 1,35 & 0,08 & 2,71 & 5,08 & 7,41 & 2,74 & 0,53 & 0,46 & 0,46 & 0,08 & 0,36 & 0,02 & 0,07 \\
\hline DGATE & 1,24 & 0,98 & 0,12 & 4,33 & 7,01 & 28,80 & 4,64 & 0,22 & 0,77 & 0,73 & 0,08 & 0,02 & 0,93 & 0,03 \\
\hline ESCOM & 3,79 & 3,77 & 0,16 & 0,02 & 0,14 & - & 0,13 & 0,97 & 0,03 & 0,03 & 0,02 & 0,02 & 0,03 & 1 \\
\hline INDES & 1,19 & 0,89 & 0,18 & 2,81 & 5,65 & 16,82 & 2,93 & 0,16 & 0,82 & 0,81 & 0,09 & 0,61 & 0,07 & 0,04 \\
\hline KÂREL & 1,88 & 0,97 & 0,04 & 0,89 & 2,91 & 2,05 & 1,20 & 0,38 & 0,62 & 0,40 & 0,06 & 0,16 & 0,29 & 0,24 \\
\hline KRONT & 3,61 & 3,53 & 0,28 & 0,60 & 1,29 & 5,68 & 0,85 & 0,79 & 0,20 & 0,19 & 0,18 & 0,23 & 0,38 & 0,81 \\
\hline LINK & 13,40 & 13,38 & 9,97 & 0,44 & 3,5 & 82,85 & 0,60 & 0,89 & 0,11 & 0,05 & 0,17 & 0,20 & 0,19 & 0,84 \\
\hline LOGO & 1,41 & 1,38 & 0,45 & 0,72 & 3,02 & 95,46 & 1,70 & 0,54 & 0,45 & 0,30 & 0,14 & 0,27 & 0,04 & 0,79 \\
\hline NETAS & 1,39 & 1,12 & 0,21 & 0,78 & 1,62 & 9,54 & 0,96 & 0,37 & 0,63 & 0,59 & 0,04 & 0,09 & 0,02 & 0,15 \\
\hline PKART & 1,86 & 1,46 & 0,26 & 1,96 & 5,75 & 8,34 & 2,34 & 0,52 & 0,47 & 0,46 & 0,06 & 0,09 & 0,04 & 0,07 \\
\hline Ortalama & 2,60 & 2,28 & $\mathbf{0 , 8 6}$ & 1,42 & 3,34 & 20,90 & 1,66 & $\mathbf{0 , 5 0}$ & 0,49 & $\mathbf{0 , 4 1}$ & $\mathbf{0 , 0 7}$ & $\mathbf{0 , 1 9}$ & 0,16 & $\mathbf{0 , 3 3}$ \\
\hline
\end{tabular}


Tablo 4 BIST'de faaliyet gösteren teknoloji firmalarının 2017 yılı likidite, faaliyet, finansal yapı ve kârlılık oranları verilmiştir. Analiz sonucunda likidite oranları sektör ortalamaları cari oran, likidite oranı ve nakit oranı sırasıyla 2,6- 2,28 ve 0,86 dir. Cari orana bakıldığında sektör ortalamasının üstünde 3 firma bulunurken sektör ortalamasının altında 11 firma bulunmaktadır. Likidite oranında sektör ortalamasının üstünde 3 firma bulunurken sektör ortalamasının altında 11 firma bulunmaktadır. Nakit oranında ise sektör ortalamasının üstünde 1 firma bulunurken sektör ortalamasının altında 13 firma bulunmaktadır. Cari oran, likidite oranı ve nakit oranları kritik değerin üstünde değerler olduğundan firmaların likidite düzeylerinin yeterli olduğu görülmektedir.

Analiz sonucunda faaliyet oranları sektör ortalamaları aktif devir hızı, alacak devir hızı, stok devir hızı, dönen varlık devir hızı sırasıyla 1,42- 3,34- 20,90 ve 1,66 dur. Aktif devir hızına bakıldığında sektör ortalamasının üstünde 6 firma bulunurken sektör ortalamasının altında 8 firma bulunmaktadır. Alacak devir hızına bakıldığında sektör ortalamasının üstünde 7 firma bulunurken sektör ortalamasının altında 7 firma bulunmaktadır. Stok devir hızına bakıldığında sektör ortalamasının üstünde 3 firma bulunurken sektör ortalamasının altında 11 firma bulunmaktadır. Dönen varlık devir hızına bakıldığında sektör ortalamasının üstünde 7 şirket bulunurken sektör ortalamasının altında 7 şirket bulunmaktadır. Dönen varlık devir hızı düşük seviyelerde seyretmesi firmaların gereğinden fazla dönen varlıklara sahip olduğunu göstermektedir. 2017 yılında teknoloji firmalarının faaliyet oranlarına bakıldığında aktif devir hızının yüksek seviyelerde olduğu görülmektedir. Alacak devir hızının ve stok düzeyinin 2016 yılına göre yüksek olması firmaların alacak tahsil yeteneğinin olumlu yönde ilerlediğinin ve stok düzeyinin arttı̆̆ını göstermektedir.

Analiz sonucunda finansal yapı oranları sektör ortalamaları öz kaynak oranı, borç oranı ve kısa vadeli yabancı kaynak oranı sırasıyla $0,50-0,49$ ve 0,41 olarak bulunmuştur. Öz kaynak oranı sektör ortalamasının üstünde 6 firma bulunurken sektör ortalamasının altında 8 firma bulunmaktadır. Borç oranı sektör ortalamasının üstünde 8 firma bulunurken sektör ortalamasının altında 6 firma bulunmaktadır. Kısa vadeli yabancı kaynak sektör ortalamasının üstünde 7 firma bulunurken sektör ortalamasının altında 7 firma bulunmaktadır. 2017 yılı teknoloji firmalarının finansal durumuna bakılırsa firmaların aktiflerinin daha çok öz kaynakla finanse edildiği görülmektedir. Borçlanma oranının 0,49 düzeyinde seyretmesi bu firmaların aktiflerinin yabancı kaynaklarla karşılanma oranını göstermektedir. Firmaların öz kaynak oranı ve borçlanma oranı aynı seviyede seyretmesi firmaların aktiflerini hem öz kaynakla hem de 
yabancı kaynaklarla finanse edildiğini göstermektedir. Kısa vadeli yabancı kaynak oranının kritik değere uyum sağlaması firmaların sağlam yapısını ortaya koymaktadır.

Analiz sonucunda kârlılık oranları sektör ortalamaları aktif kârlılık, öz kaynak kârlılık, net kâr marjı ve brüt kâr marjı sirasıyla 0,07- 0,19- 0,16 ve 0,33'dir. Aktif kârlılık sektör ortalaması üstünde 7 firma bulunurken sektör ortalamasının altında 7 firma bulunmaktadır. Öz kaynak kârlılık sektör ortalaması üstünde 6 firma bulunurken sektör ortalamasının altında 8 firma bulunmaktadır. Net kâr marjı sektör ortalamasının üstünde 5 firma bulunurken sektör ortalamasının altında 9 firma bulunmaktadır. Brüt kâr marjı sektör ortalamasının üstünde 4 firma bulunurken sektör ortalamasının altında 10 firma bulunmaktadır. Aktif kârlılık oranının yüksek seviyelerde olmaması firmaların varlıklarını verimli kullanamadığını göstermektedir. Öz kaynak kârlılık ortalamasının aktif kârlılık ortalamasına göre yüksek olması firmaların iyi yatırımlar yaptığını ve giderlerini kontrol altında tuttukları söylenebilir. Ancak yine de çok yüksek düzeylere ulaşılmamıştır. Net kâr marjının ve brüt kâr marjının düşük seviyelerde seyretmesi şirketlerin giderleri karşılamada güçlük çekebileceğini göstermektedir. Sektör 2017 yılında kârlılık oranları pek başarılı değildir. 
Tablo 5

BIST Teknoloji Sektöründe Faaliyet Gösteren Firmaların 2018 yılı Oran Analizi Sonuçları

\begin{tabular}{|c|c|c|c|c|c|c|c|c|c|c|c|c|c|c|}
\hline \multirow{2}{*}{ FİRMA } & \multicolumn{3}{|c|}{ LIKİDİTE ORANLARI } & \multicolumn{4}{|c|}{ FAALIYET ORANLARI } & \multicolumn{3}{|c|}{$\begin{array}{l}\text { FINANSAL YAPI } \\
\text { ORANLARI }\end{array}$} & \multicolumn{4}{|c|}{ KÂRLILIK ORANLARI } \\
\hline & $\mathrm{CO}$ & LO & NO & AKDH & ADH & SDH & DVDH & ÖO & BO & KVYKO & AK & ÖK & NK & BRTK \\
\hline ALCTL & 2,83 & 2,23 & 0,53 & 0,98 & 2,13 & 4,60 & 1,16 & 0,46 & 0,54 & 0,30 & 0,06 & 0,15 & 0,06 & 0,25 \\
\hline ARENA & 1,64 & 1,23 & 0,09 & 2,51 & 4,84 & 9,73 & 2,57 & 0,40 & 0,59 & 0,59 & 0,0008 & 0,0022 & 0,0003 & 0,05 \\
\hline ARMDA & 1,94 & 1,73 & 0,37 & 2,1 & 2,94 & 13,51 & 2,12 & 0,26 & 0,74 & 0,51 & $-0,0012$ & $-0,0052$ & $-0,0006$ & 0,05 \\
\hline ASELS & 2,48 & 1,65 & 0,66 & 0,58 & 3,5 & 2,18 & 1,02 & 0,52 & 0,48 & 0,24 & 0,15 & 0,31 & 0,25 & 0,24 \\
\hline DESPC & 2,82 & 2,10 & 0,04 & 3,08 & 4,62 & 8,01 & 3,13 & 0,65 & 0,35 & 0,35 & 0,18 & 0,31 & 0,06 & 0,08 \\
\hline DGATE & 1,70 & 1,59 & 0,59 & 2,29 & 5,61 & 19,34 & 2,49 & 0,44 & 0,56 & 0,54 & 0,05 & 0,18 & 0,02 & 0,04 \\
\hline ESCOM & 4,65 & 4,61 & 0,24 & 0,02 & 0,20 & - & 0,15 & 0,97 & 0,02 & 0,03 & $-0,12$ & $-0,12$ & $-6,34$ & 1 \\
\hline INDES & 1,37 & 1,09 & 0,39 & 2,18 & 4,92 & 11,54 & 2,29 & 0,23 & 0,70 & 0,69 & 0,07 & 0,35 & 0,03 & 0,04 \\
\hline KÂREL & 1,42 & 0,81 & 0,20 & 1,11 & 3,35 & 1,95 & 1,38 & 0,35 & 0,65 & 0,59 & 0,10 & 0,28 & 0,09 & 0,32 \\
\hline KRONT & 2,40 & 2,31 & 0,59 & 0,65 & 1,58 & 5,82 & 1,05 & 0,75 & 0,24 & 0,24 & 0,08 & 0,11 & 0,13 & 0,84 \\
\hline LINK & 14,66 & 14,65 & 11,58 & 0,42 & 3,63 & 173,55 & 0,57 & 0,88 & 0,12 & 0,05 & 0,26 & 0,30 & 0,63 & 0,84 \\
\hline LOGO & 1,72 & 1,68 & 0,61 & 0,68 & 2,92 & 106,71 & 1,65 & 0,52 & 0,43 & 0,23 & 0,14 & 0,27 & 0,21 & 0,80 \\
\hline NETAS & 1,30 & 0,99 & 0,18 & 0,64 & 1,33 & 9,61 & 0,79 & 0,36 & 0,63 & 0,61 & $-0,05$ & $-0,14$ & $-0,08$ & 0,13 \\
\hline PKART & 2,35 & 1,84 & 0,74 & 2,14 & 6,77 & 7,96 & 2,54 & 0,63 & 0,37 & 0,35 & 0,06 & 0,11 & 0,03 & 0,08 \\
\hline Ortalama & 3,09 & 2,75 & 1,20 & 1,38 & 3,45 & 28,81 & 1,64 & $\mathbf{0 , 5 3}$ & 0,46 & $\mathbf{0 , 3 8}$ & $\mathbf{0 , 0 7}$ & 0,15 & $-0,35$ & 0,34 \\
\hline
\end{tabular}


Tablo 5 BIST de faaliyet gösteren teknoloji firmalarının 2018 y1lı likidite, faaliyet, finansal yapı ve kârlılık oranları verilmiştir. Analiz sonucunda likidite oranları cari oran, likidite oranı ve nakit oran sektör ortalamaları sırasıyla 3,09-2,75 ve 1,20 olarak bulunmuştur. Cari oran sektör ortalaması üstünde 2 firma bulunurken sektör ortalamasının altında 12 firma bulunmaktadır. Likidite oranı sektör ortalamasının üstünde 2 firma bulunurken sektör ortalamasının altında 12 firma bulunmaktadır. Nakit oranda ise sektör ortalamasının üstünde 1 firma bulunurken sektör ortalamasının altında 13 firma bulunmaktadır. Cari oran, likidite oranı ve nakit oran değerleri kritik değerlerin altına düşmediğinden firmaların likidite düzeylerinin yeterli olduğu görülmektedir.

Analiz sonucunda faaliyet oranları aktif devir hızı, alacak devir hızı, stok devir hızı, dönen varlık devir hızı sektör ortalamaları sırasıyla 1,38- 3,45- 28,81 ve 1,64'dır. Aktif devir hızı sektör ortalamasının üstünde 6 firma bulunurken sektör ortalamasının altında 8 firma bulunmaktadır. Alacak devir hızı sektör ortalamasının üstünde 7 firma bulunurken sektör ortalamasının altında 7 firma bulunmaktadır. Stok devir hızı sektör ortalamasının üstünde 2 firma bulunurken sektör ortalamasının altında 12 firma bulunmaktadır. Dönen varlık devir hızı sektör ortalamasının üstünde 7 firma bulunurken sektör ortalamasının altında 7 firma bulunmaktadır. Dönen varlık devir hızı düşük seviyelerde seyretmesi şirketlerin gereğinden fazla dönen varlıklara sahip olduğunu göstermektedir. 2018 yılı teknoloji firmalarının faaliyet oranlarına bakıldığında aktif devir hızının yüksek seviyede olması, alacak devir hızının ve stok düzeyinin yüksek olması şirketlerin maddi duran varlıklara yüksek yatırımlar yaptığını göstermektedir. Alacak tahsil yeteneğinin iyi ve stok düzeyinin yüksek olduğu görülmektedir. Firmaların likiditelerinin yüksek olduğu ve aktiflerini başarılı bir şekilde kullandığı gözükmektedir.

Analiz sonucunda finansal yapı oranları öz kaynak oranı, borçlanma oranı ve kısa vadeli yabancı kaynak oranı sektör ortalamaları sırasıyla $0,53-0,46$ ve 0,38 dır. Öz kaynak oranı sektör ortalamasının üstünde 5 firma bulunurken sektör ortalamasının altında 9 firma bulunmaktadır. Borçlanma oranı sektör ortalamasının üstünde 8 firma bulunurken sektör ortalamasının altında 6 firma bulunmaktadır. Kısa vadeli yabancı kaynak oranında ise sektör ortalamasının üstünde 6 firma bulunurken sektör ortalamasının altında 8 firma bulunmaktadır. 2018 yılı finansal yapı oranları incelendiğinde öz kaynak oranının kritik değerden yüksek olması aktiflerin daha çok öz kaynakla finanse edildiğini göstermektedir. Borçlanma oranının kritik değerin altında olması ve kısa vadeli yabancı kaynak oranının 1/3 kritik değerine yakın olması firmaların sağlam bir finansal yapısının olduğunu göstermektedir. 
Analiz sonucunda kârlılık oranları aktif kârlılık, öz kaynak kârlılık, net kâr marjı ve brüt kâr marjı sektör ortalamaları sırasıyla 0,07- 0,15- (-0,35) ve 0,34 dir. Aktif kârlılık sektör ortalamasının üstünde 7 firma bulunurken sektör ortalamasının altında 7 firma bulunmaktadır. Öz kaynak kârlılık oranında sektör ortalamasının üstünde 7 firma bulunurken sektör ortalamasının altında 7 firma bulunmaktadır. Net kâr marjı sektör ortalamasının üstünde 13 şirket bulunurken sektör ortalamasının altında 1 şirket bulunmaktadır. Brüt kâr marjı sektör ortalamasının üstünde 4 firma bulunurken sektör ortalamasının altında 10 firma bulunmaktadır. 2018 yılı kârlılık oranları incelendiğinde özellikle net kar marjının negatif seviyelerde seyretmesi firmaların maliyetlerinin yüksek, kârlarının düşük olduğu göstermektedir. 2018 yılında teknoloji firmalarının 2017 yılına göre karlılık açısından başarısız bir yıl geçirdiği gözlemlenmektedir. 
Tablo 6

BIST Teknoloji Sektöründe Faaliyet Gösteren Firmaların 2019 yılı Oran Analizi Sonuçları

\begin{tabular}{|c|c|c|c|c|c|c|c|c|c|c|c|c|c|c|}
\hline \multirow{2}{*}{ FİRMA } & \multicolumn{3}{|c|}{ LIKİDİTE ORANLARI } & \multicolumn{4}{|c|}{ FAALIYET ORANLARI } & \multicolumn{3}{|c|}{$\begin{array}{c}\text { FINANSAL YAPI } \\
\text { ORANLARI }\end{array}$} & \multicolumn{4}{|c|}{ KÂRLILIK ORANLARI } \\
\hline & $\mathrm{CO}$ & LO & NO & AKDH & ADH & SDH & DVDH & ÖO & BO & KVYKO & $\mathbf{A K}$ & ÖK & NK & BRTK \\
\hline ALCTL & 2,08 & 1,66 & 0,69 & 0,99 & 2,40 & 5,88 & 1,15 & 0,37 & 0,63 & 0,42 & $-0,04$ & $-0,09$ & $-0,04$ & 0,10 \\
\hline ARENA & 1,58 & 1,2 & 0,19 & 2,93 & 5,62 & 10,38 & 3,02 & 0,37 & 0,63 & 0,61 & 0,03 & 0,07 & 0,01 & 0,05 \\
\hline ARMDA & 1,50 & 1,36 & 0,28 & 2,05 & 3,16 & 16,62 & 2,10 & 0,24 & 0,75 & 0,65 & 0,009 & 0,03 & 0,0044 & 0,05 \\
\hline ASELS & 1,80 & 1,17 & 0,45 & 0,58 & 3,92 & 2,14 & 1,02 & 0,53 & 0,47 & 0,30 & 0,15 & 0,28 & 0,26 & 0,26 \\
\hline DESPC & 2,05 & 1,45 & 0,03 & 2,07 & 3,44 & 7,42 & 2,11 & 0,51 & 0,48 & 0,48 & 0,09 & 0,16 & 0,03 & 0,08 \\
\hline DGATE & 1,87 & 1,41 & 0,11 & 3,63 & 5,38 & 18,70 & 2,78 & 0,29 & 0,52 & 0,52 & 0,06 & 0,21 & 0,03 & 0,06 \\
\hline ESCOM & 8,76 & 8,67 & 0,27 & 0,014 & 0,30 & - & 0,06 & 0,96 & 0,04 & 0,04 & $-0,21$ & $-0,22$ & $-14,32$ & 1 \\
\hline INDES & 1,27 & 0,96 & 0,15 & 2,61 & 5,46 & 15,008 & 2,74 & 0,18 & 0,76 & 0,76 & 0,04 & 0,23 & 0,02 & 0,05 \\
\hline KÂREL & 1,57 & 1,10 & 0,50 & 0,85 & 3,24 & 2,22 & 1,02 & 0,34 & 0,66 & 0,53 & 0,12 & 0,35 & 0,14 & 0,27 \\
\hline KRONT & 1,89 & 1,86 & 0,27 & 0,84 & 2,38 & 16,38 & 1,51 & 0,67 & 0,33 & 0,29 & 0,17 & 0,24 & 0,20 & 0,78 \\
\hline LINK & 9,14 & 9,12 & 6,99 & 0,43 & 4,91 & 135,43 & 0,57 & 0,86 & 0,14 & 0,08 & 0,21 & 0,24 & 0,47 & 0,85 \\
\hline LOGO & 1,55 & 1,53 & 0,63 & 0,63 & 2,88 & 136,66 & 1,40 & 0,48 & 0,49 & 0,31 & 0,13 & 0,26 & 0,20 & 0,82 \\
\hline NETAS & 1,26 & 0,93 & 0,16 & 0,71 & 1,51 & 9,33 & 0,92 & 0,27 & 0,73 & 0,60 & $-0,08$ & $-0,26$ & $-0,11$ & 0,12 \\
\hline PKART & 2,02 & 1,69 & 0,67 & 2,24 & 9,20 & 8,5 & 2,73 & 0,57 & 0,43 & 0,41 & 0,09 & 0,15 & 0,04 & 0,07 \\
\hline Ortalama & 2,74 & 2,44 & 0,81 & 1,47 & 3,84 & 29,58 & 1,65 & 0,47 & $\mathbf{0 , 5 0}$ & $\mathbf{0 , 4 3}$ & 0,05 & 0,11 & $-0,93$ & $\mathbf{0 , 3 2}$ \\
\hline
\end{tabular}


Tablo 6 BIST de faaliyet gösteren teknoloji firmalarının 2019 yılı likidite, faaliyet, finansal yapı ve kârlılık oranları verilmiştir. Analiz sonucunda likidite oranları cari oran, likidite oranı ve nakit oran sektör ortalamaları sırasıyla 2,74- 2,44 ve 0,81 dır. Cari oran sektör ortalamasının üstünde 2 firma bulunurken sektör ortalamasının altında 12 firma bulunmaktadır. Likidite oran sektör ortalamasının üstünde 2 firma bulunurken sektör ortalamasının altında 12 firma bulunmaktadır. Nakit oran sektör ortalamasının üstünde 1 firma bulunurken sektör ortalamasının altında 13 firma bulunmaktadır. Firmaların 2019 yılı cari oran, likidite oranı ve nakit oranı geçen yıla oranla düşüş yaşanmasına rağmen kritik değerin üstünde olmaları firmaların likidite düzeylerinin yeterli olduğunu göstermektedir.

Analiz sonucunda faaliyet oranları aktif devir hızı, alacak devir hızı, stok devir hız1, dönen varlık devir hızı sektör ortalamaları sırasıyla 1,47- 3,84- 29,58 ve 1,65 dır. Aktif devir hızı sektör ortalamasının üstünde 6 firma bulunurken sektör ortalamasının altında 8 firma bulunmaktadır. Alacak devir hızı sektör ortalamasının üstünde 6 firma bulunurken sektör ortalamasının altında 8 firma bulunmaktadır. Stok devir hızı sektör ortalamasının üstünde 2 firma bulunurken sektör ortalamasının altında 12 firma bulunmaktadır. Dönen varlık devir hızı sektör ortalamasının üstünde 6 firma bulunurken sektör ortalamasının altında 8 firma bulunmaktadır. 2019 yılında faaliyet oranlarının kritik değerlerin üzerinde olması firmaların aktiflerini başarılı bir şekilde kullandığını göstermektedir. Firmaların likidite düzeyleri yüksektir.

Analiz sonucunda finansal yapı oranları öz kaynak oranı, borçlanma oranı ve kısa vadeli yabancı kaynak oranı sektör ortalamaları sırayla $0,47-0,50$ ve 0,43 dir. Öz kaynak oranı sektör ortalamasının üstünde 7 firma bulunurken sektör ortalamasının altında 7 firma bulunmaktadır. Borçlanma oranı sektör ortalamasının üstünde 7 firma bulunurken sektör ortalamasının altında 7 firma bulunmaktadır. Kısa vadeli yabancı kaynak oranı sektör ortalamasının üstünde 7 firma bulunurken sektör ortalamasının altında 7 firma bulunmaktadır. 2019 yılı finansal yapı oranları incelendiğinde öz kaynak oranının kritik değere yakın olması, borçlanma oranının kritik değerde seyretmesi ve kısa vadeli yabancı kaynak oranının 1/3 kritik değerine yakın olması firmaların sağlam bir finansal yapısının devam ettiğini göstermektedir. Yıllar arasında çok fazla bir değişim yaşanmaması firmaların finansal başarılarına işarettir.

Analiz sonucunda kârlılık oranları aktif kârlılık, öz kaynak kârlılık, net kâr marjı ve brüt kâr marjı sırasıyla 0,05- 0,11- (-0,93) ve 0,32 dür. Aktif kârlılık sektör ortalamasının üstünde 8 firma bulunurken sektör ortalamasının altında 6 firma bulunmaktadır. Öz kaynak kârlılık sektör ortalamasının üstünde 9 firma bulunurken sektör ortalamasının altında 5 firma bulunmaktadır. 
Net kâr marjı sektör ortalamasının üstünde 13 firma bulunurken sektör ortalamasının altında 1 firma bulunmaktadır. Brüt kâr marjı sektör ortalamasının üstünde 4 firma bulunurken sektör ortalamasının altında 10 şirket bulunmaktadır. 2019 yılı kârlılık oranları incelendiğinde aktif kârlılık ve öz kaynak kârlılık oranlarının bir önceki yıla göre daha düşük seviyede olduğu görülmektedir. Net kâr marjının negatif seyretmesi ve brüt kâr marjının bir önceki yıla göre düşmesi kârlılı̆̆ın olumsuz olduğunu göstermektedir. 
Tablo 7

BIST Teknoloji Sektöründe Faaliyet Gösteren Firmaların 2020 yılı Oran Analizi Sonuçları

\begin{tabular}{|c|c|c|c|c|c|c|c|c|c|c|c|c|c|c|}
\hline \multirow{2}{*}{ FİRMA } & \multicolumn{3}{|c|}{ LİKİDİTE ORANLARI } & \multicolumn{3}{|c|}{ FAALIYET ORANLARI } & ORANL & \multicolumn{3}{|c|}{ FINANSAL YAPI } & \multicolumn{4}{|c|}{ KÂRLILIK ORANLARI } \\
\hline & $\mathrm{CO}$ & LO & NO & AKDH & ADH & SDH & DVDH & ÖO & BO & KVYKO & $\mathbf{A K}$ & ÖK & NK & BRTK \\
\hline ALCTL & 1,82 & 1,40 & 0,47 & 1,21 & 2,27 & 4,26 & 1,27 & 0,35 & 0,64 & 0,49 & 0,02 & 0,05 & 0,02 & 0,13 \\
\hline ARENA & 1,52 & 1,12 & 0,21 & 3,57 & 6,68 & 13,48 & 3,68 & 0,35 & 0,65 & 0,63 & 0,04 & 0,12 & 0,01 & 0,05 \\
\hline ARMDA & 1,44 & 1,25 & 0,20 & 2,18 & 2,9 & 15,33 & 2,23 & 0,20 & 0,79 & 0,68 & 0,01 & 0,04 & 0,005 & 0,04 \\
\hline ASELS & 1,59 & 1,11 & 0,33 & 0,54 & 2,82 & 2,09 & 0,96 & 0,52 & 0,47 & 0,36 & 0,15 & 0,28 & 0,27 & 0,28 \\
\hline DESPC & 1,53 & 1,20 & 0,07 & 3,07 & 4,19 & 10,55 & 3,13 & 0,35 & 0,64 & 0,64 & 0,09 & 0,23 & 0,03 & 0,05 \\
\hline DGATE & 1,55 & 1,07 & 0,06 & 3,63 & 5,14 & 12,71 & 3,73 & 0,27 & 0,63 & 0,63 & 0,05 & 0,19 & 0,02 & 0,04 \\
\hline ESCOM & 3,33 & 3,20 & 0,21 & 0,004 & 1,48 & - & 0,022 & 0,96 & 0,03 & 0,03 & 0,41 & 0,43 & 9,27 & 1 \\
\hline INDES & 1,16 & 0,99 & 0,39 & 3,17 & 5,35 & 20,46 & 3,28 & 0,14 & 0,83 & 0,83 & 0,04 & 0,29 & 0,01 & 0,04 \\
\hline KÂREL & 1,41 & 0,98 & 0,42 & 0,77 & 2,98 & 2,47 & 0,94 & 0,33 & 0,67 & 0,58 & 0,09 & 0,27 & 0,11 & 0,23 \\
\hline KRONT & 1,53 & 1,51 & 0,38 & 0,59 & 1,66 & 12,63 & 1,04 & 0,58 & 0,41 & 0,39 & 0,11 & 0,19 & 0,19 & 0,82 \\
\hline LINK & 12,63 & 12,63 & 10,68 & 0,42 & 4,98 & 132,32 & 0,55 & 0,88 & 0,11 & 0,06 & 0,26 & 0,30 & 0,61 & 0,84 \\
\hline LOGO & 1,34 & 1,32 & 0,72 & 0,58 & 2,89 & 81,45 & 1,18 & 0,46 & 0,51 & 0,37 & 0,12 & 0,26 & 0,21 & 0,82 \\
\hline NETAS & 1,06 & 0,84 & 0,18 & 0,78 & 1,90 & 9,74 & 1,04 & 0,24 & 0,76 & 0,71 & $-0,03$ & $-0,12$ & $-0,04$ & 0,10 \\
\hline PKART & 2,83 & 1,58 & 0,88 & 2,65 & 10,95 & 8,24 & 3,22 & 0,69 & 0,31 & 0,29 & 0,07 & 0,12 & 0,03 & 0,06 \\
\hline Ortalama & 2,48 & 2,15 & 1,08 & 1,65 & 4,01 & 25,05 & 1,48 & 0,45 & $\mathbf{0 , 5 3}$ & 0,48 & 0,10 & 0,19 & 0,77 & 0,32 \\
\hline
\end{tabular}


Tablo 7 BIST de faaliyet gösteren teknoloji firmalarının 2020 yılı likidite, faaliyet, finansal yapı ve kârlılık oranları verilmiştir. Analiz sonucunda likidite oranları cari oran, likidite oranı ve nakit oran sektör ortalamaları sirasıyla 2,48-2,15 ve 1,08 dır. Cari oran sektör ortalamasının üstünde 3 firma bulunurken sektör ortalamasının altında 11 firma bulunmaktadır. Likidite oranı sektör ortalamasının üstünde 2 firma bulunurken sektör ortalamasının altında 12 firma bulunmaktadır. Nakit oran sektör ortalamasının üstünde 1 firma bulunurken sektör ortalamasının altında 13 firma bulunmaktadır. Firmaların cari oran, likidite oranı ve nakit oranı bir önceki yıla göre düşüş göstermiştir. Ancak yine de oranlar kritik değerlerin üstünde seyretmektedir. Firmaların likidite düzeyleri yeterli gözükmektedir.

Analiz sonucunda faaliyet oranları aktif devir hızı, alacak devir hızı, stok devir hızı, dönen varlık devir hızı sektör ortalamaları sırasıyla 1,65-4,01- 25,05 ve 1,48' dır. Aktif devir hızı sektör ortalamasının üstünde 6 firma bulunurken sektör ortalamasının altında 8 firma bulunmaktadır. Alacak devir hızı sektör ortalamasının üstünde 6 firma bulunurken sektör ortalamasının altında 8 firma bulunmaktadır. Stok devir hızı sektör ortalamasının üstünde 2 firma bulunurken sektör ortalamasının altında 12 firma bulunmaktadır. Dönen varlık devir hızı sektör ortalamasının üstünde 6 firma bulunurken sektör ortalamasının altında 8 firma bulunmaktadır. 2020 yılında faaliyet oranları 2019 yılına göre aktif devir hızı ve alacak devir hızında artışlar yaşanmıştır. Şirketlerin stok devir hızı ve dönen varlık hızında bir önceki yıla göre düşüş gerçekleşmiştir.

Analiz sonucunda finansal yapı oranları öz kaynak oranı, borçlanma oranı ve kısa vadeli yabancı kaynak oranı sektör ortalamaları sırasıyla 0,45- 0,53 ve 0,48 dir. Öz kaynak oranı sektör ortalamasının üstünde 6 firma bulunurken sektör ortalamasının altında 8 firma bulunmaktadır. Borçlanma oranı sektör ortalamasının üstünde 8 firma bulunurken sektör ortalamasının altında 6 firma bulunmaktadır. Kısa vadeli yabancı kaynak oranı sektör ortalamasının üstünde 8 firma bulunurken sektör ortalamasının altında 6 firma bulunmaktadır. Finansal yapı oranları öz kaynak oranı bir önceki yıla göre düşüş gözlenirken borçlanma oranı ve kısa vadeli yabancı kaynak oranı bir önceki yıla göre artmıştır.

Analiz sonucunda kârlılık oranları aktif kârlılık, öz kaynak kârlılık, net kâr marjı ve brüt kâr marjı sektör ortalamaları sirasıyla 0,10- 0,19- 0,77 ve 0,32 dir. Aktif kârlılık sektör ortalamasının üstünde 5 firma bulunurken sektör ortalamasının altında 9 firma bulunmaktadır. Öz kaynak kârlılık sektör ortalamasının üstünde 9 firma bulunurken sektör ortalamasının altında 5 
firma bulunmaktadır. Net kâr marjı sektör ortalamasının üstünde 1 firma bulunurken sektör ortalamasının altında 13 firma bulunmaktadır. Brüt kâr marjı sektör ortalamasının üstünde 4 firma bulunurken sektör ortalamasının altında 10 firma bulunmaktadır. Bir önceki yıla göre firmaların kârlılık oranlarında artışlar yaşanmıştır.

\section{Sonuç ve Öneriler}

Bu çalışmada BIST işlem gören teknoloji şirketlerinin finansal performansları 2016-2020 dönemleri bilanço ve gelir tablolarından yararlanılarak oran analizi tekniği ile likidite durumları, finansal yapıları, faaliyet durumları ve kârlılık oranları ölçülmüştür.

Yapılan analiz sonucunda ele alınan yıllarda firmaların likidite durumlarının herhangi bir risk içermediği ve yeterli düzeyde olduğu görülmüştür. Covid-19 salgınının etkili olduğu 2020 yılında firmaların cari ve likidite oranlarında düşüş görülse de yine de kritik değerlerin üzerinde olduğu tespit edilmiştir. Endeksteki firmaların cari oran ortalamalarının ele alınan yıllar içerisinde ideal olan değer 2' den yüksek olduğu görülmektedir. Nakit oran ise 2020 yılında artış göstermiştir. Böylelikle firmaların kısa vadeli borç ödeyebilme yeteneklerinin salgında da yüksek olduğu görülmektedir. Endeksteki firmaların likidite oran ortalamalarının ele alınan yıllar içerisinde ideal değer olan 1' den yüksek olduğu görülmektedir. Endeksteki firmaların nakit oran ortalamalarının ele alınan yıllar içerisinde ideal değer olan 0.20'nin üzerinde olduğu görülmektedir. LINK firması ele alınan yıllarda sektör ortalamasının üzerinde cari oran, likidite ve nakit oranına sahip firmalardır. NETAS firması ise ele alınan yıllarda sektör ortalamasının çok altında kalarak nakit sıkıntısı içerisinde bulunduğu söylenebilir. Diğer firmaların ise dalgalı yapıda oldukları görülmektedir. Tayyar, Akcanlı, Genç ve Erem (2014), tarafindan yapılan çalışmada en yüksek performansa sahip teknoloji şirketi LINK firması olarak bulunmuştur.

Faaliyet oranları incelendiğinde firmaların aktiflerini başarılı bir şekilde kullandıklarını göstermektedir. Covid-19 salgın döneminde de şirketlerin aktif devir hızında yükseliş görülmektedir. Böylelikle endeksteki firmaların ele alınan yıllar içerinde aktiflerini verimli kullandıkları sonucuna ulaşılmaktadır. 2020 yılında alacak devir hızında artış gözlenmektedir. Şirketlerin alacak tahsil sürelerinin uzadığı tespit edilmiştir. Ele alınan dönem içerisinde stok devir hızı ve dönen varlık devir hızı yüksek seviyelerdeyken 2020 yılında düşüş yaşanmıştır. Yani şirketlerin stoklarını tüketme hızı düşmüştür. DGATE, PKART ve LINK şirketleri ele alınan yıllar 
içerisinde sektör ortalamasının üzerinde faaliyet sergilerken ESCOM şirketi yıllar itibariyle sektör ortalamasının çok altında kalmıştır.

Firmaların finansal yapıları incelendiğinde firmaların çoğunun sermaye yapılarının öz sermaye ile oluşturulduğu gözlemlenmektedir. Şirketlerin öz kaynak oranı kritik değer \%50 seviyelerinde seyretmiştir. Ancak 2020 yılında öz kaynak oranı düşmüş ve şirketler daha çok borçlanma yoluna gitmiştir özellikle 2019 ve 2020 yılında borçlanma oranı kritik değerin üzerinde seyretmiş ve kısa vadeli yabancı kaynak oranında artış yaşanmıştır. Covid-19 salgının etkili olduğu dönemde şirketler daha çok borçlanma yoluna gitmiş, kısa vadeli yabancı kaynak oranları artmış, öz kaynak oranı ele alınan yıllar içerisinde en düşük seviyeye gelmiştir. Öz kaynak oranı en yüksek firma ESCOM firmasıdır. Borçlanma ve kısa vadeli yabancı kaynak oranı en yüksek firma INDES'dir.

Kârlılık oranları incelendiğinde ise yıllar içerisinde firmaların dalgalı bir seyirde ilerlediği ve 2018-2019 yıllarında negatif seviyelere düştüğü gözlemlenmektedir. Ancak salgın döneminde firmaların karlılık oranlarının yükseldiği tespit edilmiştir. Aktif karlılık, öz kaynak karlılık, net kar marjı ve brüt kar marjı 2020 yılında artmıştır. ESCOM ve LINK firması ele alınan yıllarda yüksek kâr marjına sahiptir.

Çalışma sonucunda firmaların özellikle Covid-19 döneminde likidite düzeylerini korumaları, finansal yapılarında öz kaynak oranının daha fazla artırılması, kısa vadeli yabancı kaynak oranını azaltarak risklerini minimize etmeleri ve satış maliyetlerini düşürerek kârlılıklarını artırmaları önerilebilir. Finansal oranları sektör ortalamasının altında kalan firmaların ise finans ve satış politikalarını tekrar gözden geçirmeleri gerekmektedir. Yeni teknik ve çözümler geliştirerek oranlarını sektör ortalamasının üstüne çekmeleri önerilmektedir. Çalışmadan elde edilen sonuçların, Covid-19'un etkilerine yönelik yapılan diğer çalışmalarda elde edilen bulgularla uyumlu tespit edilmiştir.

\section{Kaynakça}

Akgüç, Ö. (2004). Mali Tablolar Analizi, 11. Baskı, Arayış Yayıncılık, İstanbul.

Allıanz Araştırmalar. (2020b). Her Taşın Altına Bakmak: Covid-19'un Sektör Bazında Olumsuz Etkileri. Erişim adresi: https:/www.eulerhermes.com/content/dam/onemarketing/ ehndbx/eulerhermes_com/tr_TR/documents/allianz-rapor-dizgi.pdf. 
Arat, M. E. (2005). Finansal Analiz Aracı Olarak Oranlar Illkeler \& Yorumlar, Yaylım Matbaası, İstanbul

Aslam, F., Aziz, S., Nguyen, D. K., Mughal, K. S. \& Khan, M. (2020). On The Efficiency of Foreign Exchange Markets in Times of the COVID-19 Pandemic, Technological Forecasting and Social Change, 161.

Bakır, H. \& Şahin, C. (2009). Finansal Tablolar Analizi,1.Baskı Detay Yayıncılık Ankara.

Baur, Dirk G. \& Trench, A. (2020). Covid-19 Infection of Australian Companies. Erişim adresi: https://ssrn.com/abstract=3609110.

Berk, N. (1998). Finansal Yönetim, Türkmen Kitabevi, İstanbul.

Büyükşalvarcı, A. (2011). Finansal Analizde Kullanılan Oranlar Ve Hisse Senedi Getirileri Arasındaki İlişki: Ekonomik Kriz Dönemleri İçin IMKB İmalat Sanayi Şirketleri Üzerine Ampirik Bir Uygulama, Atatürk Üniversitesi Iktisadi ve İdari Bilimler Dergisi, Cilt:25, Say1:1, s.225-240.

Çabuk, A. \& Lazol, İ. (2009). Mali Tablolar Analizi, Ekin Kitabevi, Bursa.

Elsayed, A. \& Abdelrhim, M. (2020). The Effect Of COVID-19 Spread On Egyptian Stock Market Sectors. Erişim adresi: http://dx.doi.org/10.2139/ssrn.3608734.

Erdoğan, M. (2011). Finansal Yönetim, 2. Baskı, Aktif Yayınevi, Erzurum.

Gümüş, F.B. \& Aydemir, L. (2014). 2008 Küresel Finans Krizinin Sektörel Bazda Şirket Mali Tablolarına Etkilerinin Analizi. İsletme Bilimi Dergisi, 2(1), s:37-64.

Hamim, Md T. (2020). Covid-19 and the Capital Market Chaos. Erişim adresi: http://dx.doi.org/10.2139/ssrn.3600853

http://www.finnet.com.tr/f2000/finansalanaliz/SektorOran.aspx, Erişim Tarihi: 18.04.2021.

https://www.eulerhermes.com/content/dam/onemarketing/ehndbx/common/tr_TR/documents/eco nomik-yay\%C4\%B1nlar/EH high stakes2017.pdf, Erişim Tarihi: 18.12.2020.

https://www.kap.org.tr/tr/, Erişim Tarihi: 20.05.2021.

Kandil Göker, İ , Eren, B. \& Karaca, S . (2020). The Impact of the Covid-19 (coronavirus) on the Borsa İstanbul Sector Index Returns: An Event Study. Gaziantep University Journal of Social Sciences, 19 (Covid-19 Special Issue), s:14-41.

Liu, H., Wang, Y., He, D. \& Wang, C. (2020). Short Term Response of Chinese Stock Markets to the Outbreak of Covid-19, Applied Economics.

Şenol, Z. \& Zeren, F. (2020). Coronavirus (Covid-19) and Stock Markets: The Effects of the Pandemic on the Global Economy, Avrasya Sosyal ve Ekonomi Araştırmaları Dergisi, 7(4), s: $1-16$. 
Tayyar N., Akcanlı F., Genç E. \& Erem I.(2014). BİST e Kayıtlı Bilişim ve Teknoloji Alanında Faaliyet Gösteren İşletmelerin Finansal Performanslarının Analitik Hiyerarşi Prosesi (AHP) ve Gri İlişkisel Analiz (GİA) Yöntemiyle Değerlendirilmesi, Muhasebe ve Finansman Dergisi, 61, s.19-40

TCMB Finansal İstikrar Raporu (2020). TCMB Finansal İstikrar Raporu Say1:30.

Uyar, A., \& Okumuş, E. (2010). Finansal oranlar aracılığıyla küresel ekonomik krizin üretim sirketlerine etkilerinin analizi: IMKB'de bir uygulama, Muhasebe ve Finansman Dergisi, 46, $146-156$. 